\title{
TINGKAT PENGETAHUAN DAN SIKAP MEMANDIKAN BAYI DAN MERAWAT TALI PUSAT OLEH IBU POST PARTUM
}

\author{
Militia Christy Aprilia Sundalangi ${ }^{1,}$ Sefty S.J. Rompas ${ }^{2}$ Maria Lupita N. Meo ${ }^{3}$ \\ ${ }^{1}$ Mahasiswa Program Studi Ilmu Keperawatan Fakultas Kedokteran Universitas Sam \\ Ratulangi \\ ${ }^{2,3}$ Program Studi Ilmu Keperawatan Fakultas Kedokteran Universitas Sam Ratulangi \\ Email :militiachristy7@gmail.com
}

\begin{abstract}
The knowledge and attitude of bathing a baby are very important aspects in parenting work. Also to caring for the umbilical cord is the principal thing to notice by mothers regarding newborn care. Lacking of knowledge and attitude in bathing a baby and caring for the umbilical cord could affect the health of the baby. The purpose of this research is to describe the level of knowledge and attitude of baby bathing and caring for the umbilical cord of post-partum mother in Warisa village of Talawaan district of North Minahasa regency. The research method that was used on this research is descriptive research design with survey method. The sample research used the total population model. The total respondent was 33 respondents of post-partum mothers in the Warisa village of Talawaan district of North Minahasa regency. The results showed that from 33 respondents, there were 13 respondents (39.4\%) those who have good knowledge in bathing babies, there were 13 respondents $(39.4 \%)$ those who have lacking knowledge to caring for the umbilical cord, there were 23 respondents (69.7\%) those who have negative attitude in bathing babies and there were 19 respondents (57,6\%) those who have a negative attitude in caring for the umbilical cord. Conclusion the results of this research were displayed that there were many levels of knowledge in bathing babies and caring for the umbilical cord of the post-partum in Warisa village of North Minahasa Regency. The author suggests that the health services should have been able to see and maximize the needs of the knowledge level and attitude toward newborn care, specifically in terms of post-partum mothers, in bathing the baby and caring for the umbilical cord by improving the level education for the related issues.
\end{abstract}

Keywords: Knowledge, Attitude, Baby Bathing, Umbilical Cord.

\begin{abstract}
Abstrak : Pengetahuan dan sikap memandikan bayi dan merawat tali pusat merupakan hal penting yang harus diperhatikan oleh ibu dalam perawatan bayi baru lahir. Pengetahuan yang kurang serta sikap yang tidak baik dalam memandikan bayi dan merawat tali pusat dapat mempengaruhi kesehatan bayi. Tujuan penelitian untuk mengetahui gambaran tingkat pengetahuan dan sikap memandikan bayi dan merawat tali pusat oleh ibu post partum di Desa Warisa Kecamatan Talawaan Kabupaten Minahasa Utara Metode penelitian ini menggunakan desain penelitian deskriptif dengan metode survey. Sampel penelitian ini menggunakan total populasi yaitu seluruh ibu post partum di Desa Warisa Kecamatan Talawaan Kabupaten Minahasa Utara sebanyak 33 responden. Hasil penelitian menunjkkan bahwa dari 33 responden 13 responden $(39,4 \%)$ memiliki pengetahuan baik dalam memandikan bayi, 13 responden $(39,4 \%)$ memiliki pengetahuan kurang dalam pengetahuan merawat tali pusat, 23 responden $(69,7 \%)$ memiliki sikap negatif dalam memandikan bayi dan 19 responden $(57,6 \%)$ memiliki sikap negatif dalam merawat tali pusat . Kesimpulan, hasil penelitian ini mendapatkan gambaran tingkat pengetahuan memandikan bayi dan merawat tali pusat oleh ibu post partum di Desa Warisa Kecamatan Talawaan Kabupaten Minahasa Utara. Saran, Bagi pihak pelayanan kesehatan yang ada diharapkan dapat melihat dan memaksimalkan kebutuhan tingkat pengetahuan dan sikap perawatan bayi baru lahir lebih khusus dalam hal memandikan bayi dan
\end{abstract}


merawat tali pusat oleh ibu post partum dengan meningkatkan edukasi dalam hal memandikan bayi dan merawat tali pusat.

Kata Kunci : Pengetahuan, Sikap, Memandikan Bayi, Merawat Tali Pusat.

\section{PENDAHULUAN}

Masa nifas atau postpartum adalah masa sesudah melahirkan atau persalinan sampai beberapa jam sesudah lahirnya plasenta atau tali pusat sampai minggu ke enam setelah melahirkan. Ibu akan mengalami adaptasi fisik dan adaptasi psikologis selama masa nifas. Adaptasi fisik meliputi kembalinya fungsi organ tubuh sedangkan adaptasi psikologis adalah transisi peran sebagai orang tua (Green, 2012). Bedasarkan Riset Kesehatan dasar sebagian besar ibu belum memahami cara perawatan bayi baru lahir, dikarenakan pengetahuan,sikap dan pengalaman ibu yang rendah. Hal ini membuat ibu merasa takut, cemas dan bingung dalam perawatan bayi baru lahir termasuk cara memandikan bayi dan perawatan tali pusat (Nursalam dkk, 2005).

Jika keadaan ini dapat terus-menerus terjadi, maka akan mempengaruhi kesehatan bayi mereka. Ibu harus mempersiapkan diri dengan meningkatkan pengetahuan dalam melakukan perawatan bayi baru lahir, karena kemampuan ibu dalam melakukan perawatan tali pusat dan memandikan bayi dipengaruhi ibu sejak awal, jika ibu tidak memiliki pengetahuan dan sikap yang baik, maka ibu akan mengalami kesulitan dalam menjalankan peran baru sebagai ibu dan jika perawatan bayi baru lahir tidak dilakukan dengan benar, akan dapat menimbulkan dampak yang tidak baik jika tidak melakukan tindakan perawatan seperti memandikan bayi dan merawat tali pusat secara baik dan benar bisa saja virus, bakteri dapat masuk ke dalam tubuh bayi melalui tali pusat jika bayi tidak dimandikan dan dibersihkan secara benar karena bayi sangat sensitive dengan dengan penyakit. (Friedman dkk, 2003).

Bayi sangat rentan terserang penyakit karena belum memiliki daya imun yang sempura, oleh karena itu ibu harus memperhatikan cara perawatan bayi secara tepat dan komprehensif (Putra, 2012) agar bakteri atau virus tidak masuk ke tubuh bayi.

Berdasarkan pengambilan data awal yang dilakukan peneliti di Desa Warisa Kecamatan Talawaan Kabupaten Minahasa Utara, didapatkan sebanyak $30 \mathrm{ibu}$ post partum minnggu ke 6 sampai dengan ke 8 pasca persalinan dan Desa Warisa merupakan wilayah kerja dari Puskesmas Talawaan. Pada saat pengambilan data peneliti mendapatkan banyak ibu yang yang sudah mengerti tapi masih merasa takut untuk memandikan bayi dan perawatan tali pusat secara mandiri dan harus dibantu oleh orang tua. Ada juga yang sudah bisa melakukannya sendiri tapi mereka menyadari belum memahami secara benar tentang perawatan bayi baru lahir dalam hal ini memandikan bayi dan perawatan tali pusat. Apalagi di Desa Warisa masih percaya akan perawatan-perawatan zaman dulu seperti contohnya untuk merawat tali pusat setelah bayi dimandikan biasanya masih ada orang tua yang menggunakan parutan arang tempurung untuk diberikan ditali pusat bayi guna untuk mempercepat puputnya tali pusat. Berdasarkan latar belakang di atas, peneliti ingin mengetahui seperti apa pengetahuan dan sikap memandikan bayi dan merawat tali pusat oleh ibu post partum di Desa Warisa Kecamatan Talawaan Kabupaten Minahasa Utara saat saat merawat bayinya.

\section{METODE PENELITIAN}

Jenis penelitian ini menggunakan penelitian deskriptif dengan metode survey untuk mengidentifikasi gambaran sikap ibu dalam memandikan bayi dan perawatan tali pusat di Desa Warisa Kecamatan Talawaan, Kabupaten Minahasa Utara. Penelitian ini telah dilakukanPenelitian ini telah dilakukan pada bulan Mei-Juni 2020. 
Dalam penelitian ini yang menjadi populasi adalah ibu post partum di Desa Warisa Kecamatan Talawaan Kabupaten Minahasa Utara berjumlah33 orang. Sampel dalam penelitian ini meliputi subjek yang memenuhi kriteria ibu yang pernah mengalami persalinan pada maksimal di minggu $6-8$ pasca persalinan, tidak masuk dalam PDP atau terinfeksi Virus Covid-19, dapat membaca dan bersedia menjadi responden.

untuk mengetahui sikap ibu tentang memandikan bayi.

Instrument dalam penelitian ini menggunakan kuisioner. Dalam kuisioner pengetahuan memandikan bayi akan diukur sampai tahap pengaplikasian apakah ibu sudah melakukan dengan baik atau tidak dalam memandikan bayi dan pengukuran pengaplikasiannya akan diukur melalui kuisioner yang akan diberikan pada ibu. Untuk menilai pengetahuan ibu dilakukan penyekoran yang menyediakan dua alternative jawaban, yaitu : (a) bila jawaban "benar" skornya 1 (satu); (b) jika jawaban "salah" skornya 0 (nol), Dalam kuisioner pengetahuan merawat tali pusat akan diukur sampai tahap pengaplikasian apakah ibu sudah melakukan dengan baik atau tidak dalam merawat tali pusat dan pengukuran pengaplikasiannya akan diukur melalui kuisioner yang akan diberikan pada ibu. Untuk menilai pengetahuan ibu dilakukan penyekoran yang menyediakan dua alternative jawaban, yaitu : (a) bila jawaban "benar" skornya 1 (satu) ; (b) jika jawaban "salah" skornya 0 (nol). Sikap dalam memandikan bayi menggunakan kuisioner berisikan 20 pertanyaan untuk mengetahui sikap ibu tentang memandikan bayi dengan menggunakan tiga kategori pertanyaan sebagai berikut: a) bila bentuk pertanyaan positif, dengan jawaban : sangat setuju (SS) skornya 3, setuju (S) skornya 2, tidak setuju (TS) skornya 1 ; b) bila bentuk pertanyaan negatif dengan jawaban : sangat setuju (SS) skornya 1, setuju (S) skornya 2, tidak setuju (TS) skornya 3. Instrument yang digunakan dalam penelitian ini tentang sikap merawat tali pusat menggunakan kuisioner dengan
10 pernyataan.Dalam Skala Likert, terdapat beberapa kategori yaitu Sangat Setuju (SS) diberi skor 5, Setuju (S) diberi skor 4, Ragu - Ragu (RR) diberi skor 3, Tidak Setuju (TS) diberi skor 2, Sangat Tidak Setuju (STS) diberi skor 1.

Pengolahan data yang diperoleh dari hasil penelitian ini diolah secara manual dengan mengelompokkan hasil dari kuisioner kemudian dilakukan analisis menggunakan uji statistik setelah itu diolah meggunakan sistem komputersasi, tahap-tahap tersebut yairu editing, coding, processing, dan cleaning. Data lalu di analisis univariat melalui uji statistik komputer.

\section{HASIL dan PEMBAHASAN}

A. HASIL

1. Karakteristik Responden

Tabel 1. Distribusi Frekuensi Responden Menurut Usia

\begin{tabular}{lll}
\hline Usia & $\mathbf{n}$ & \% \\
\hline $20-23$ & 5 & 15,2 \\
$24-36$ & 26 & 78,8 \\
$>36$ & 2 & 6,1 \\
& & \\
\hline Total & 33 & 100 \\
\hline
\end{tabular}

Sumber : Data Primer, 2020

Tabel 2 Distribusi Frekuensi menurut Pendidikan

\begin{tabular}{lll}
\hline Pendidikan & n & \% \\
\hline SMP & 1 & 3,0 \\
SMA & 18 & 54,5 \\
S1 & 14 & 42,4 \\
\hline Total & 33 & 100
\end{tabular}

Sumber : data Primer, 2020 
Tabel 3 Distribusi Frekuensi Menurut Pekerjaan

\begin{tabular}{lll}
\hline Pekerjaan & n & \% \\
\hline ASN & 10 & 30,3 \\
IRT & 16 & 48,5 \\
Karyawan & 1 & 3,0 \\
Swasta & 5 & 15,2 \\
Mahasiswa & 1 & 3,0 \\
Pedagang & & \\
\hline Total & 33 & 100
\end{tabular}

Sumber : Data Primer, 2020

\section{Analisa Univariat}

Tabel 4 Distribusi Frekuensi Responden Berdasarkan Pengetahuan Memandikan bayi

\begin{tabular}{lll}
\hline \multicolumn{1}{c}{ Pengetahuan } & n & \% \\
\hline Kurang & 8 & 24,2 \\
Cukup & 12 & 36,4 \\
Baik & 13 & 39,4 \\
\hline Total & 33 & 100
\end{tabular}

Sumber : data Primer, 2020

Tabel 5 Distribusi Frekuensi Responden berdasarkan komponen pengetahuan memandikan bayi

\begin{tabular}{|c|c|c|c|c|c|c|}
\hline \multirow{2}{*}{$\begin{array}{c}\text { Identifikasi } \\
\text { komponen } \\
\text { pengetahuan } \\
\text { memandikan } \\
\text { bayi }\end{array}$} & \multicolumn{2}{|c|}{ Benar } & \multicolumn{2}{|c|}{ Salah } & \multirow{2}{*}{$\begin{array}{c}\text { Mean } \\
\text { (SD) }\end{array}$} & \multirow[t]{2}{*}{ Prioritas } \\
\hline & $\mathbf{f}$ & $\%$ & $\mathbf{f}$ & $\%$ & & \\
\hline $\begin{array}{l}\text { Manajemen } \\
\text { memandikan } \\
\text { bayi secara } \\
\text { benar }\end{array}$ & 8 & 24,2 & 25 & 75,7 & $\begin{array}{c}1.75 \\
(0,88)\end{array}$ & 1 \\
\hline $\begin{array}{l}\text { Hal-hal yang } \\
\text { diperhatikan } \\
\text { dalam } \\
\text { memandikan } \\
\text { bayi }\end{array}$ & 10 & 30,3 & 23 & 69,7 & $\begin{array}{c}1.69 \\
(0,81)\end{array}$ & 2 \\
\hline $\begin{array}{l}\text { Waktu } \\
\text { Memandikan } \\
\text { Bayi }\end{array}$ & 17 & 51,5 & 16 & 48,5 & $\begin{array}{c}1.48 \\
(0,81)\end{array}$ & 3 \\
\hline $\begin{array}{l}\text { Pengertian } \\
\text { Memandikan } \\
\text { Bayi }\end{array}$ & 23 & 69,7 & 10 & 30,3 & $\begin{array}{c}1.30 \\
(0,75)\end{array}$ & 4 \\
\hline Total Score & & & & & $\begin{array}{c}1,55 \\
(0,81) \\
\end{array}$ & \\
\hline
\end{tabular}

Data Primer 2020
Tabel 6 Distribusi Frekuensi Responden Pengetahuan Memandikan Bayi berdasarkan Usia

\begin{tabular}{ccccccccc}
\hline \multirow{3}{*}{ Usia } & \multicolumn{4}{c}{ Pengetahuan } & \multicolumn{2}{c}{ Total } \\
\cline { 2 - 7 } & \multicolumn{2}{c}{ Kurang } & \multicolumn{2}{c}{ Cukup } & \multicolumn{2}{c}{ Baik } & \\
\cline { 2 - 7 } & $\mathbf{n}$ & $\%$ & $\mathbf{n}$ & $\%$ & $\mathbf{n}$ & $\%$ & $\mathbf{n}$ & $\%$ \\
\hline $20-23$ & 0 & 0 & 3 & 60 & 2 & 40 & 5 & 100 \\
$24-36$ & 8 & 30,8 & 9 & 34,6 & 9 & 34,6 & 26 & 100 \\
$>36$ & 0 & 0 & 0 & 0 & 2 & 100 & 2 & 100 \\
\hline Total & 8 & 24,2 & 12 & 36,4 & 13 & 39,4 & 33 & 100 \\
\hline
\end{tabular}

Sumber Data Primer 2020

Tabel 7 Distribusi Frekuensi Responden Pengetahuan Memandikan Bayi berdasarkan Pendidikan

\begin{tabular}{ccccccccc}
\hline \multirow{3}{*}{ Pendidikan } & \multicolumn{9}{c}{ Pengetahuan } & \multicolumn{3}{c}{ Total } \\
\cline { 2 - 7 } & \multicolumn{2}{c}{ Kurang } & \multicolumn{2}{c}{ Cukup } & \multicolumn{2}{c}{ Baik } & & \\
\cline { 2 - 7 } & $\mathbf{n}$ & $\%$ & $\mathbf{n}$ & $\%$ & $\mathbf{n}$ & $\%$ & $\mathbf{n}$ & $\%$ \\
\hline SMP & 1 & 100 & 0 & 0 & 0 & 0 & 1 & 100 \\
SMA & 4 & 22,2 & 8 & 44,4 & 6 & 33,4 & 18 & 100 \\
S1 & 3 & 21,4 & 4 & 28,6 & 7 & 50 & 14 & 100 \\
\hline Total & 8 & 24,2 & 12 & 36,4 & 13 & 39,4 & 33 & 100 \\
\hline
\end{tabular}

Sumber Data Primer 2020

Tabel $8 \quad$ Distribusi $\quad$ Frekuensi RespondenPengetahuan Memandikan Bayi berdasarkan Pekerjaan

\begin{tabular}{ccccccccc}
\hline \multirow{3}{*}{ Pekerjaan } & \multicolumn{9}{c}{ Pengetahuan } & \multicolumn{2}{c}{ Total } \\
\cline { 2 - 7 } & \multicolumn{1}{c}{ Kurang } & \multicolumn{2}{c}{ Cukup } & \multicolumn{2}{c}{ Baik } & \\
\cline { 2 - 7 } & $\mathbf{n}$ & $\%$ & $\mathbf{n}$ & $\%$ & $\mathbf{n}$ & $\%$ & $\mathbf{n}$ & $\%$ \\
\hline ASN & 1 & 10 & 2 & 20 & 7 & 70 & 10 & 100 \\
IRT & 6 & 37,5 & 6 & 37,5 & 4 & 25 & 16 & 100 \\
Mahasiswa & 0 & 0 & 3 & 60 & 2 & 40 & 5 & 100 \\
Karyawan & 1 & 100 & 0 & 0 & 0 & 0 & 1 & 100 \\
Swasta & & & & & & & & \\
Pedagang & 0 & 0 & 1 & 100 & 0 & 0 & 1 & 100 \\
\hline Total & 8 & 24,2 & 12 & 36,4 & 13 & 39,4 & 33 & 100 \\
\hline
\end{tabular}

Sumber Data Primer 2020

Tabel 9 Distribusi Frekuensi Responden Berdasarkan Pengetahuan Merawat Tali Pusat

\begin{tabular}{lll}
\hline Pengetahuan & n & \% \\
\hline Kurang & 13 & 39,4 \\
Cukup & 12 & 36,4 \\
Baik & 8 & 24,2 \\
\hline Total & 33 & 100
\end{tabular}

Sumber : data Primer, 2020 
Tabel 10 Distribusi Frekuensi Responden berdasarkan komponen pengetahuan merawat tali pusat

\begin{tabular}{|c|c|c|c|c|c|c|}
\hline \multirow{2}{*}{$\begin{array}{c}\text { Identifikasi } \\
\text { komponen } \\
\text { pengetahua } \\
\text { n merawat } \\
\text { tali pusat }\end{array}$} & \multicolumn{2}{|c|}{ Benar } & \multicolumn{2}{|c|}{ Salah } & \multirow{2}{*}{$\begin{array}{c}\text { Mean } \\
\text { (SD) }\end{array}$} & \multirow{2}{*}{$\begin{array}{c}\text { Pri } \\
\text { orit } \\
\text { as }\end{array}$} \\
\hline & $\mathbf{f}$ & $\%$ & $\mathbf{f}$ & $\%$ & & \\
\hline $\begin{array}{l}\text { Tanda dan } \\
\text { gejala } \\
\text { infeksi pada } \\
\text { tali pusat }\end{array}$ & 6 & 18,2 & 1.81 & 81,8 & $\begin{array}{c}1.81 \\
(0,68)\end{array}$ & 1 \\
\hline $\begin{array}{l}\text { Manajemen } \\
\text { perawatan } \\
\text { tali pusat }\end{array}$ & 8 & 24,2 & 1.75 & 75,7 & $\begin{array}{c}1.75 \\
(0,75)\end{array}$ & 2 \\
\hline $\begin{array}{l}\text { Kebersihan } \\
\text { dalam } \\
\text { merawat tali } \\
\text { pusat }\end{array}$ & 19 & 57,6 & 1.42 & 42,4 & $\begin{array}{c}1.42 \\
(0,87)\end{array}$ & 3 \\
\hline Total Score & & & & & $\begin{array}{c}1,66 \\
(0,76)\end{array}$ & \\
\hline
\end{tabular}

Data Primer 2020

Tabel 11 Distribusi Frekuensi RespondenPengetahuan Merawat Tali Pusat berdasarkan Usia

\begin{tabular}{ccccccccc}
\hline \multirow{3}{*}{ Usia } & \multicolumn{5}{c}{ Pengetahuan } & \multicolumn{3}{c}{ Total } \\
\cline { 2 - 7 } & Kurang & \multicolumn{2}{c}{ Cukup } & \multicolumn{2}{c}{ Baik } & \\
\cline { 2 - 7 } & $\mathbf{n}$ & $\%$ & $\mathbf{n}$ & $\%$ & $\mathbf{n}$ & $\%$ & $\mathbf{n}$ & $\%$ \\
\hline $20-23$ & 2 & 40 & 3 & 60 & 0 & 0 & 100 \\
$24-36$ & 10 & 38,5 & 9 & 34,6 & 7 & 26,9 & 100 \\
$>36$ & 1 & 50 & 0 & 0 & 1 & 50 & 100 \\
\hline Total & 13 & 39,4 & 12 & 36,4 & 8 & 24,2 & 33 & 100
\end{tabular}

Sumber Data Primer 2020

Tabel 12 Distribusi Frekuensi RespondenPengetahuan Merawat Tali Pusat berdasarkan Pendidikan

\begin{tabular}{cccccccccc}
\hline \multirow{2}{*}{ Pendidikan } & \multicolumn{3}{c}{ Pengetahuan } & \multicolumn{3}{c}{ Total } \\
\cline { 2 - 6 } & \multicolumn{2}{c}{ Kurang } & \multicolumn{2}{c}{ Cukup } & \multicolumn{2}{c}{ Baik } & & \\
\cline { 2 - 7 } & n & $\%$ & n & $\%$ & n & $\%$ & n & $\%$ \\
\hline SMP & 0 & 0 & 1 & 100 & 0 & 0 & 1 & 100 \\
SMA & 9 & 50 & 7 & 38,9 & 2 & 11,1 & 18 & 100 \\
S1 & 4 & 28,6 & 4 & 28,6 & 6 & 42,8 & 14 & 100 \\
\hline Total & 13 & 39,4 & 12 & 36,4 & 8 & 24,2 & 33 & 100
\end{tabular}

Sumber Data Primer 2020
Tabel 13 Distribusi Frekuensi RespondenPengetahuan merawat tali pusat berdasarkan Pekerjaan

\begin{tabular}{ccccccccc}
\hline & \multicolumn{4}{c}{ Pengetahuan } & \multicolumn{3}{c}{ Total } \\
\cline { 2 - 7 } Pekerjaan & Kurang & \multicolumn{2}{c}{ Cukup } & \multicolumn{2}{c}{ Baik } & \\
\cline { 2 - 7 } & $\mathbf{n}$ & $\%$ & $\mathbf{n}$ & $\%$ & $\mathbf{n}$ & $\%$ & $\mathbf{n}$ & $\%$ \\
\hline ASN & 1 & 10 & 3 & 20 & 6 & 60 & 10 & 100 \\
IRT & 9 & 56,2 & 6 & 37,5 & 1 & 6,3 & 16 & 100 \\
Mahasiswa & 1 & 20 & 3 & 60 & 1 & 20 & 5 & 100 \\
Karyawan & 1 & 100 & 0 & 0 & 0 & 0 & 1 & 100 \\
Swasta & & & & & & & & \\
Pedagang & 1 & 100 & 0 & 0 & 0 & 0 & 1 & 100 \\
\hline Total & 13 & 39,4 & 12 & 36,4 & 8 & 24,2 & 33 & 100 \\
\hline Sumber & & & & & & & &
\end{tabular}

Sumber Data Primer 2020

Tabel 14 Distribusi Frekusensi Responden Berdasarkan Sikap Memandikan Bayi

\begin{tabular}{lll}
\hline Sikap & n & \% \\
\hline Negatif & 23 & 69,7 \\
Positif & 10 & 30,3 \\
\hline Total & 33 & 100 \\
\hline
\end{tabular}

Sumber : data Primer, 2020

Tabel 15 Distribusi Frekuensi Responden berdasarkan komponen sikap memandikan bayi

\begin{tabular}{|c|c|c|c|c|c|c|}
\hline \multirow{2}{*}{$\begin{array}{c}\text { Identifikasi } \\
\text { komponen } \\
\text { sikap } \\
\text { memandikan } \\
\text { bayi }\end{array}$} & \multicolumn{2}{|c|}{ Benar } & \multicolumn{2}{|c|}{ Salah } & \multirow{2}{*}{$\begin{array}{c}\text { Mean } \\
\text { (SD) }\end{array}$} & \multirow[t]{2}{*}{ Prioritas } \\
\hline & f & $\%$ & $\mathbf{f}$ & $\%$ & & \\
\hline $\begin{array}{l}\text { Persiapan } \\
\text { dalam } \\
\text { memandikan } \\
\text { bayi }\end{array}$ & 3 & 9,1 & 30 & 90,9 & $\begin{array}{c}1.90 \\
(0,50)\end{array}$ & 1 \\
\hline $\begin{array}{l}\text { Cara } \\
\text { memandikan } \\
\text { baik secara } \\
\text { benar }\end{array}$ & 12 & 36,4 & 21 & 63,6 & $\begin{array}{c}1.63 \\
(0,85)\end{array}$ & 2 \\
\hline $\begin{array}{l}\text { Sikap } \\
\text { manajemen } \\
\text { memandikan } \\
\text { bayi }\end{array}$ & 18 & 54,5 & 15 & 45,5 & $\begin{array}{c}1.45 \\
(0,88)\end{array}$ & 3 \\
\hline Total Score & & & & & $\begin{array}{c}1,66 \\
(0,74)\end{array}$ & \\
\hline
\end{tabular}

Data Primer 2020 
Tabel 16 Distribusi Frekuensi RespondenSikap Memandikan Bayi berdasarkan Usia

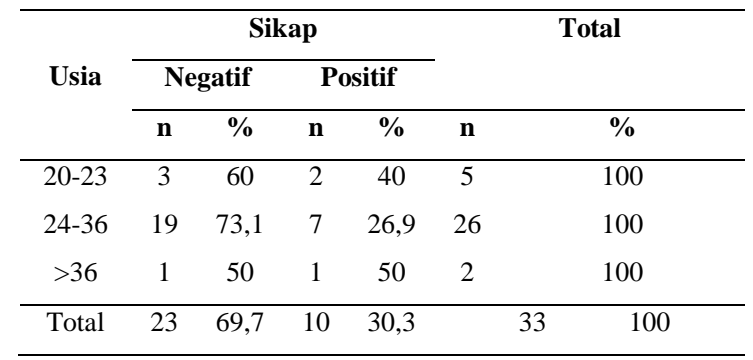

Sumber Data Primer 2020

Tabel 17 Distribusi Frekuensi Responden Sikap Memandikan Bayi berdasarkan Pendidikan

\begin{tabular}{ccccccc}
\hline \multirow{2}{*}{ Pendidikan } & \multicolumn{4}{c}{ Sikap } & \multicolumn{2}{c}{ Total } \\
\cline { 2 - 5 } & \multicolumn{2}{c}{ Negatif } & \multicolumn{2}{c}{ Positif } & \\
\cline { 2 - 6 } & $\mathbf{n}$ & $\%$ & $\mathbf{n}$ & $\%$ & $\mathbf{n}$ & $\%$ \\
\hline SMP & 1 & 100 & 0 & 0 & 1 & 100 \\
SMA & 13 & 72,2 & 5 & 27,8 & 18 & 100 \\
S1 & 9 & 64,3 & 5 & 35,7 & 14 & 100 \\
\hline Total & 23 & 69,7 & 10 & 30,3 & 33 & 100
\end{tabular}

Sumber Data Primer 2020

Tabel 18 Distribusi Frekuensi RespondenSikap Memandikan Bayi berdasarkan Pekerjaan

\begin{tabular}{ccccccc}
\hline \multirow{2}{*}{ Pekerjaan } & \multicolumn{3}{c}{ Sikap } & \multicolumn{2}{c}{ Total } \\
\cline { 2 - 5 } & \multicolumn{2}{c}{ Negatif } & \multicolumn{2}{c}{ Positif } & \\
\cline { 2 - 6 } & N & $\%$ & n & $\%$ & n & $\%$ \\
\hline ASN & 6 & 60 & 4 & 40 & 10 & 100 \\
IRT & 12 & 75 & 4 & 25 & 16 & 100 \\
Mahasiswa & 3 & 60 & 2 & 40 & 5 & 100 \\
Karyawan & 1 & 100 & 0 & 0 & 1 & 100 \\
Swasta & 1 & 100 & 0 & 0 & 1 & 100 \\
Pedagang & 1 & 69,7 & 10 & 30,3 & 33 & 100
\end{tabular}

Sumber Data Primer 2020

Tabel 19 Distribusi Frekuensi Responden Berdasarkan Sikap Merawat Tali Pusat

\begin{tabular}{lll}
\hline Sikap & n & \% \\
\hline Negatif & 19 & 57,6 \\
Positif & 14 & 42,4 \\
\hline Total & 33 & 100
\end{tabular}

Sumber : data Primer, 2020
Tabel 20 Distribusi Frekuensi Responden berdasarkan komponen sikap merawat tali pusat

\begin{tabular}{|c|c|c|c|c|}
\hline \multirow{2}{*}{$\begin{array}{c}\text { Identifikasi } \\
\text { komponen } \\
\text { sikap } \\
\text { merawat } \\
\text { tali pusat }\end{array}$} & Benar & Salah & \multirow{2}{*}{$\begin{array}{c}\text { Mean } \\
\text { (SD) }\end{array}$} & \multirow[t]{2}{*}{ Prioritas } \\
\hline & f $\%$ & $\%$ & & \\
\hline $\begin{array}{l}\text { Cara } \\
\text { perawatan } \\
\text { tali pusat }\end{array}$ & $10 \quad 30,3$ & $23 \quad 69,7$ & $\begin{array}{c}1.69 \\
(0,83)\end{array}$ & 1 \\
\hline $\begin{array}{l}\text { Manajemen } \\
\text { perawatan } \\
\text { tali pusat }\end{array}$ & $23 \quad 69,7$ & $\begin{array}{ll}10 & 30,3\end{array}$ & $\begin{array}{c}1.33 \\
(0,81)\end{array}$ & 2 \\
\hline Total Score & & & $\begin{array}{c}1,51 \\
(0,82)\end{array}$ & \\
\hline
\end{tabular}

Data Primer 2020

Tabel 21 Distribusi Frekuensi RespondenSikap Merawat Tali Pusat berdasarkan Usia

\begin{tabular}{ccccccc}
\hline \multirow{2}{*}{ Usia } & \multicolumn{3}{c}{ Sikap } & \multicolumn{3}{c}{ Total } \\
\cline { 2 - 5 } & \multicolumn{2}{c}{ Negatif } & \multicolumn{3}{c}{ Positif } & \\
\cline { 2 - 6 } & $\mathbf{n}$ & $\%$ & $\mathbf{n}$ & $\%$ & $\mathbf{n}$ & $\%$ \\
\hline $20-23$ & 2 & 40 & 3 & 60 & 5 & 100 \\
$24-36$ & 17 & 65,4 & 9 & 34,6 & 26 & 100 \\
$>36$ & 1 & 50 & 1 & 50 & 2 & 100 \\
\hline Total & 20 & 60,6 & 13 & 39,4 & 33 & 100 \\
\hline
\end{tabular}

Sumber Data Primer 2020

Tabel 22 Distribusi Frekuensi RespondenSikap Merawat Tali Pusat berdasarkan Pendidikan

\begin{tabular}{ccccccc}
\hline \multirow{2}{*}{ Pendidikan } & \multicolumn{3}{c}{ Sikap } & \multicolumn{2}{c}{ Total } \\
\cline { 2 - 5 } & \multicolumn{2}{c}{ Negatif } & \multicolumn{2}{c}{ Positif } & & \\
\cline { 2 - 6 } & $\mathbf{n}$ & $\%$ & $\mathbf{n}$ & $\%$ & $\mathbf{n}$ & $\%$ \\
\hline SMP & 1 & 100 & 0 & 0 & 1 & 100 \\
SMA & 10 & 55,6 & 8 & 44,4 & 18 & 100 \\
S1 & 9 & 64,3 & 5 & 35,7 & 14 & 100 \\
\hline Total & 20 & 60,6 & 13 & 39,4 & 33 & 100
\end{tabular}

Sumber Data Primer 2020 
Tabel 23 Distribusi Frekuensi RespondenSikap merawat tali pusat berdasarkan Pekerjaan

\begin{tabular}{|c|c|c|c|c|c|c|}
\hline \multirow{3}{*}{ Pekerjaan } & \multicolumn{4}{|c|}{ Sikap } & \multicolumn{2}{|c|}{ Total } \\
\hline & \multicolumn{2}{|c|}{ Negatif } & \multicolumn{2}{|c|}{ Positif } & \multirow[b]{2}{*}{$\mathbf{n}$} & \multirow[b]{2}{*}{$\%$} \\
\hline & $\mathbf{N}$ & $\%$ & $\mathbf{n}$ & $\%$ & & \\
\hline$\overline{\mathrm{ASN}}$ & 8 & 80 & 2 & 20 & 10 & 100 \\
\hline IRT & 9 & 56,3 & 7 & 43,7 & 16 & 100 \\
\hline Mahasiswa & 4 & 80 & 1 & 20 & 5 & 100 \\
\hline $\begin{array}{c}\text { Karyawan } \\
\text { swasta }\end{array}$ & 1 & 100 & 0 & 0 & 1 & 100 \\
\hline Pedagang & 0 & 0 & 1 & 100 & 1 & 100 \\
\hline Total & 22 & 66,7 & 11 & 33,3 & 33 & 100 \\
\hline
\end{tabular}

Sumber Data Primer 2020

\section{B. PEMBAHASAN}

\section{Karakteristik Responden}

a. Berdasarkan Usia

Berdasarkan karakteristiik usia, 24 sampai 36 tahun sebanyak $78,8 \%$ dari total 33 responden ini sejalan dengan yang di kemukakan oleh Novitasary dkk, 2013 Wanita Usia Subur adalah wanita yang masih dalam usia reproduktif yaitu antara usia $15-49$ tahun yang sangat berpotensi mempunyai anak. Usi seseorang sangat mempengaruhi tingkat produktivitasnya, jika usia wanita memaasuki usia lanjut maka produktivitasnya menurun karena dipenngaruhi oleh bebraapa faktor sepeerti fisik dan status kesehatannya bahkan seorang wanita memasuki masa menopausenya.

\section{b. Berdasarkan Pendidikan}

Berdasarkan pendidikan terakhir dari total 33 responden didapatkan pendidikan terakhir SMP sebanyak 1 ibu $(3,0 \%)$, pendidikan terakhur SMA sebanyak $18 \mathrm{ibu}$ (54, 5\%) dan pendidikan terakhir S1 sebanyak 14 ibu (42,4\%). Menurut Notoatmodjo 2003, kemampuan seseorang dipengaruhi oleh tigkat pendidikannya. Pendidikan yang tiggi dapat meningkatkan kematangan intelektual seseorang seinggah pengetahuan yang dimiliki dapat dikembangkan dan diterapkan dalam kehidupan sehari - hari.

c. Berdasarkan pekerjaan

Dari hasil penelitian yang dilakukan terhadap 33 responden ditemukan mayoritas pekerjaan ibu yaitu IRT sebanyak 16 ibu $(48,5 \%)$ dan minoritas pekerjaan yaitu Karyawaan Swasta sebanyak 1 ibu $(3,0 \%)$ dan pedagang sebanyak $1 \mathrm{ibu}$ (3,0\%). Menurut Notoatmodjo 2003 berpendapat bahwa pekerjaan merupakan kegiatan yang dilakukan atau diperbuat baik mendapatkan upah atau tidak.

\section{Analisa Univariat}

a. Pengetahuan Memandikan Bayi

Dari hasil penelitian didapatkan pengetahuan ibu tentang memandikan bayi dari 33 responden 8 responden berpengetahuan kurang (24,2\%), 12 responden berpengetahuan cukup $(36,4 \%)$ dan 13 responden berpengetahuan baik $(39,4 \%)$. Maka dapat disimpulkan pengetahuan ibu dalam memandikan bayi termasuk dalam kategori baik walaupun masih ada beberapa responden yang memiliki pengetahuan kurang dan cukup. Hal ini sejalan dengan temuan penelitian yang dilakukan sebelumnya, bahwasanya tingkat pengetahuan memandikan bayi menunjukkan mayoritas baik sebanyak $77,5 \%$ itu dikarenakan adanya kemauan dari ibu untuk belajar dan mencoba dalam memandikan bayi secara mandiri karena dorongan terbesar dalam diri sendirilah dapat mampu meningkatkan pengetahuan yang baik (Gozen et al.,2019).

b. Pengetahuan Merawat Tali Pusat

Dari hasil penelitian didapatkan pengetahuan responden tentang cara perawatan tali dari 33 responden, 13 responden $(39,4 \%)$ berpengetahuan kurang, berpengetahuan cukup 12 responden $(36,4 \%)$ dan responden $8(24,2 \%)$ yang berpengetahuan baik. Beberapa faktor yang mempengaruhi pengetahuan, seperti pendidikan, informasi/media massa, social budaya dan ekonomi, lingkungan, pengalaman, usia dan paritas, tapi 
seringkali hambatan terbesar tentang minimnya pengetahuan dikarenakan karena faktor dalam diri sendiri dalam menyikapi tentang pengetahuan, karena kemampuan belajar dari diri sendirilah sebagai faktor utama pengetahuan dan sikap sesorang.( Asiegbu et al.,2018)

c. Sikap Memandikan Bayi

Berdasarkan hasil penelitian dari 33 responden diketahui bahwa mayoritas ibu mempunyai sikap negatif tentang memandikan bayi yaitu sebanyak 23 responden $(69,7 \%)$, dan minoritas ibu mempunyai sikap positif sebanyak 10 responden $(30,3 \%)$.

Menurut pendapat Maulana (2009) Sikap itu respon yang masih tertutup dari seseorang terhadap suatu stimulus atau objek. Sikap tidak dapat langsung dilihat dan merupakan kesiapan untuk bereaksi terhadap objek di lingkungan tertentu sebagai suatu penghayatan terhadap objek. Sikap dipengaruhi oleh faktor internal dan eksternal. proses belajar ini terjadi karena pengalaman seseorang dengan objek tertentu dengan menghubungkan pengalaman yang satu dengan pengalaman lainyanya. Dengan banyaknya pengalaman yang diperoleh dapat membantu seseorang untuk menentukan sikap terhadap tindakan yang akan dia lakukan (Gunay et al., 2018). d. Sikap Merawat Tali Pusat

Berdasarkan penelitian menunjukkan bahwa dari 33 responden, yang memiliki sikap negatif 19 responden $(57,6 \%)$ dan 14 responden $(42,4 \%)$ yang memiliki sikap positif. . Sikap dapat diartikan sebagai kesiapan/kesediaan, proses ini tidak langsung terjadi dengan sendirinya, tetapi ada beberapa tahap salah satunya dengan proses belajar, proses belajar ini terjadi karena pengalaman seseorang dengan objek tertentu dengan menghubungkan pengalaman yang satu dengan pengalaman lainyanya. Dengan banyaknya pengalaman yang diperoleh dapat membantu seseorang untuk menentukan sikap terhadap tindakan yang akan dia lakukan. (Chingle et al.,2019)

\section{KESIMPULAN}

1. Sebagian besar ibu di Desa Warisa Kecamatan Talawaan Kabupaten Minahasa Utara memiliki tingkat pengetahuan baik dalam memandikan bayi

2. Sebagian besar ibu di Desa Warisa Kecamatan Talawaan Kabupaten Minahasa Utara memiliki tingkat pengetahuan kurang dalam merawat tali pusat pada bayi

3. Sebagian besar ibu di Desa Warisa Kecamatan Talawaan Kabupaten Minahasa Utara memiliki sikap negatif dalam memandikan bayi

4. Sebagian besar ibu di Desa Warisa Kecamatan Talawaan Kabupaten Minahasa Utara memiliki sikap negatif dalam merawat tali pusat.

5. Gambaran pengetahuan dan sikap ibu memandikan bayi dan merawat tali pusat bukan sepenuhnya hal pendidikan yang merupakan faktor utama penentu tingkat pengetahuan seseorang, karena kemampuan belajar dari diri sendirilah sebagai faktor utama pengetahuan dan sikap sesorang. Jadi pendidikan juga bisa didapat secara informal, yaitu berupa informasi-informasi dari orang lain atau berupa pengalamanpengalaman yang sudah memang dapat dibuktikan kebenarannya

\section{DAFTAR PUSTAKA}

Azwar. (2007) Sikap Manusia, Teori dan Pengukurannya.. Yogyakarta:Pustaka Belajar

Aziegbu et al. (2019).Umbilical Cord Care: The Knowledge, Attitude and Practice among Mothers in Abakaliki, Ebonyi State, South. dalam https://www.researchgate.net/profile/ Uzoma_Asiegbu/publication/333907 370_Umbilical_Cord_Care_The_Kn owledge_Attitude_and_Practice_am ong_Mothers in_Abakaliki_Ebonyi State_South/links/5d0bd94f299bf154 7c71515c/Umbilical-Cord-Care-TheKnowledge-Attitude-and-Practiceamong-Mothers-in-Abakaliki- 
Ebonyi-State-

South.pdf?origin=publication_detail

Admin Haryanto (2009). Komplikasi dalam

Perawatan Bayi Baru Lahir. Jakarta:

Salemba Medika

KBBI (2005). Kamus Besar Bahasa Indonesia (KBBI). [online] http:kbbi.web.id/pusat, diakses 10 Maret 2020

Bobak, Irene. M., Lowdermilk., and Jensen. (2010). Buku Ajar Keperawatan Maternitas. Edisi 4.Jakarta : EGC.

Budiman (2013). Kapita Selekta Kuisioner Pengetahuan dan Sikap dalam PenelitianKesehatan.Jakarta:Salemba Medika

Faisal (2007). Sinopsis Obstetri Jilid 2. Jakarta:EGC

Friedman, M.N.F., Bowden, V.R., \& Jones, E.G. (2013). Buku AjarKeperawatan Keluarga: riset, teori, \&praktik Edisi 5. Jakarta:EGC

Gozen et al. (2019). First Bathing Time of Newborn Infants after birth: A Comparative Analysis. Dalam https://onlinelibrary.wiley.com First Bathing Time of Newborn Infants after birth: A Comparative Analysis /doi/full/10.1111/jspn.12239

Green,C. J and J. M. Wilkinson. (2012). Rencana Asuhan Keperawatan Maternal \& Bayi Baru Lahir. Jakarta: EGC

Graciacendiki (2018) Tingkat Pengetahuan Memandikan Bayi di Tegineneng Lampung Selatan. dalam https://jurnal.stikesperintis.ac.id/inde x.php/JAKS/article/view/264/162 diakses pada 14 Maret 2020

Gunay et al.(2018). The Effect of Tub Bathing on the Newborn Pain: A RandommizedClinical Trial. dalam https://www.internationaljournalofca ringsciences.org/docs/56_1gunay_original_10_2.pdf
Hadijanto B, (2012). Pendarahan pada Kehamilan Muda In: Ilmu Kebidanan

Hidayat, Alimul. (2012) Metode Kebidanan Teknik Analisis Data.Jakarta: Salemba Medika

Linda (2007) Hubungan Tingkat Pengetahuan Dengan Sikap Ibu Paska MelahirkanDalam Perawatan Tali Pusat Bayi Di Wilayah Kerja Puskesmas Kupang Kabupaten Mojokerto. dalam https://ejourna.unair.ac.id/JNERS/article/dow nload/3864/2624 diakses pada 22 April 2020

Manuaba,C., Manuaba, F. \& Manuaba.2010.Gawat Darurat Obstretri Ginekologi\& Obstretri Ginekologi Sosial untuk Profesi Bidan.Jakarta:EGC

Maulana Oscar (2009). Pengetahuan dan Sikap Individu. Jakarta : Graha Ja

Marmi. (2012). Asuhan Neonatus, bayi, balita, dan anak prasekolah. Yogyakarta:Pustaka Pelajar.

Mitayani. (2010). Asuhan Keperawatan Maternitas. Salemba Medika Jakarta.

Mochtar, Rustam. (2012). Sinopsis obstetri : obstetri operatif, obstetri sosial, jilid2. Jakarta: EGC

Notoadmodjo (2007). Dasar-dasar Ilmu dan seni Metodologi Kesehatan. Jakarta: Rineka Cipta

Nugroho, Taufan. (2011). Buku Ajar Obstretri Yogjakarta: Nuha Medika

Nursalam, Susilaninggrum, R., \& Utami, S. (2005). Asuhan Keperawatan Bayi dan Anak (untuk perawat dan bidan). Jakarta: Salemba Medika

Priyono Y (2010). Merawat Bayi Tanpa Baby Sitter, Yogyakarta: Medika Pressindo.

Pujiastuti (2014). Gambaran Perawatan Tali Pusat pada Ibu Primipara di Puskesmas Banyuwangi. Dalam http://ojshafshawaty.ac.id/index.php/ 
jpengmas/article/download/6/6

diakses pada 16 April 2020

Sumampow, Andriani (2015). Metodologi Penelitian Kesehatan. Jakarta: EGC

Notoatmodjo, (2003). Metodologi Penelitian Pendidikan dan Perilaku Kesehatan. Jakarta: Bumi Aksara.

Riksani, R. (2012). Keajaiban ASI (Air Susu Ibu). Jakarta: Dunia Sehat

Saleha, Sitti. (2013). Asuhan Kebidanan Pada Masa Nifas. Jakarta : Salemba Medika

Setiadi (2013). Konsep Dan Proses Keperawatan Keluarga .Yogyakarta: Graha Ilmu.

Sodikin, (2013) Asuhan Keperawatan Anak Gangguan Sistem Gastrointestinal. Jakarta: Salemba Medika

Sulistyawati. A. (2013). Asuhan Kebidanan Pada Masa Kehamilan. Jakarta: Salemba Medika

Suherni, (2013). Perawatan Masa Nifas. Yogyakarta: Fitramaya

Wawandan Dewi, 2010, Teori dan Pengukuran Pengetahuan dan, Sikap dan Perilaku Manusia, Yogyakarta : Nuha Medika

WHO (2014). Maternal Mortality: World Health Organization. 